\title{
Institutional Analysis of Globalization: A Case of Pakistan
}

\author{
Bushra Hamid \\ Professor, Institute of Management Studies \\ University of Peshawar, Khyber Pukhtunkhwa, Pakistan \\ Nasreen Ghufran \\ Department of International Relations \\ University of Peshawar, Khyber Pukhtunkhwa, Pakistan \\ E-mail: nasreenghufran@yahoo.com
}

Received: September 20, $2010 \quad$ Accepted: March 15, $2011 \quad$ doi:10.5539/ass.v7n8p145

\begin{abstract}
The rapid growth of globalization in recent years has led to greater activity on part of the vested interests, rent-seekers and organizations to pursue their respective selfish agendas. The paper argues that the process of globalization resulted in emergence of institutions and professions that are more detrimental to global peace and prosperity. Moreover, it underscores hazards of the concepts of globalization when realized in a conceited manner. Case of Pakistan is cited to explain the course.
\end{abstract}

Keywords: Globalization, Governance, Institutions, Organizations, Terrorism

\section{INTRODUCTION}

\section{Globalization explained}

The term 'globalization' is a versatile concept having economic, social, cultural and political dimensions. Appadurai (2001) stated five types of globalization- Ethnoscapes, Financescapes, Ideoscapes, Mediascapes and Technoscapes - which essentially have to do with the global movements of people, flows of money, spread of ideas, distribution of media images and movement of technologies. On the contrary Naim (2003, pp 29-37) has cited "Five Wars of Globalization" that includes Drugs, Arms trafficking, Intellectual property, Alien smuggling and Money laundering which comprises prevalence of organized crime's involvement in cartels and smugglers, voracious demand for weapons, rampant bootlegging, piracy and illegal migration. These can be attributed as anti-globalization elements. However, in essence Globalization is a device that should benefit all segments of mankind. Therefore the affects of anti-globalization need to be addressed and controlled to promote world's peace and prosperity.

\section{Globalization \& Terrorism}

Numerous critics argue that Globalization and anti-globalization go hand in hand and that the existing terrorism in the world today can be linked to this mutual process. Besides, they further argue that "globalization has positive features and was an inexorable process that was not going away" (Rosecrance, 2003). On the contrary, Rosecrance predicted that for the next ten years there would be more episodes of terrorism and hence a corresponding "movement of abundant capital" to other financial and economic centers (Ibid).

Notwithstanding the pros and cons of globalization, economic compulsions of the $21^{\text {st }}$ century led Pakistan to integrate into the world economic system through following the dictates of WTO by liberalizing its financial and trade systems. Besides, the security compulsions directed the country to become an official ally of the US led global war on terrorism (GWOT). This paper attempts to underscore effects of the gradual and selective approach to globalization in terms of emergence of the institutions and professions that despite being beneficial in a limited way have been perilous to Pakistan's development and security agenda.

\section{GLOBALIZATION IN CONTEXT}

Globalization is considered as the most abused word of the $21^{\text {st }}$ century. The word meant differently to different people and has aroused as much sentiment, as it is perceived to be a blessing by many towards peace and 
prosperity, while others accuse it as a new kind of turmoil. However, the accelerated trend of globalization has illustrated all its benefits and destructive power. Conquest, prosperity, proselytizing and inquisitiveness are considered to be four major motives that made people to leave their dwellings. Hence the principal agents of globalization were soldiers, traders, preachers and adventurers (Chanda, 2002). Free trade is considered to be the main factor that boosted the economic growth and created a flourishing middle class which led to increased global consumption and yield. The revolution in information technology is accounted as the most potent force for spreading the ideas of democracy, human rights and press freedom. The USA is considered to be the champion of globalization by drawing upon world resources, through the 60 million people that migrated in the19th century (History of the United States). The US victory in the World War II, launch of Marshall Plan and its military power concluded in the end of Cold War. Hence globalization is identified as a symbol of Americanization by many in the world.

\section{Anti-globalization}

The awareness of the economic gap between underprivileged, the rich West, and domestic elites sponsored by the West is a dominant source of resentment and protest across the world. Hence anti-globalization is a grass root movement to counter the trend of globalization and its harmful effects, and to reform unbridled capitalism (Introduction to Anti-Globalization - Definition and Resources). The movement of goods and ideas has also provoked divergent responses. Many in the West oppose globalization as the symbol of excessive free market capitalism. On the contrary it is also perceived by others as a Western-led globalization aimed at destroying Islam (MercyCorps, 2003). No discussion on globalization is complete without a considerable reference to spread of "terrorism" globally. As globalization has shrunk the planet through free flow of people, goods, and ideas across borders; the process has been accelerated by technology while compromising the sovereignty of nation-states (MercyCorps, 2004). Terrorism, on the other hand can be related to both, to the principles of globalization and anti-globalization. It is however, imperative to understand the connection between the two.

According to Hendrik Hertzberg, "globalization relies increasingly on the principles of trust" (Ibid), that is, the unsentimental expectation that people, individually and collectively, will behave more or less in their rational self-interest. On the contrary, terrorist effectively use the doctrine of trust for their exploits. They use the technological tools of globalization and have little concern for the sovereignty of the states. In addition to others, there are two means to identify the linkage between globalization and terrorism. First, is the tendency of globalization to undermine the sovereignty of the nation state and secondly consideration of liberal democracy as the only practical form of government. The rapid stretch of globalization has resulted in growth of a network of transnational institutions that link nations through a diversified governance system. Moreover, it does not address the issue of political identity which created a vacuum to be filled by the rise of religion for the support and recognition of political identity (Bamikole). Religion thus has become one of the major source of collective identity. Being a human institution, religion also thrives on emotions which elucidate the existence of many fundamentalist religious groups (Ibid).

On one hand, religious fundamentalism is an expression of the politics of identity, advocating that the secular nature of public realm has degenerated the moral and social norms which otherwise had made societies more cohesive and peaceful. On the other hand, argument made by Rawls that, "Justice is the first virtue of social institutions ... laws and institutions, no matter how efficient and well-arranged, must be reformed or abolished if they are unjust" (1993) has irked the religious fundamentalist. The mistake made by Rawls in his argument is in understanding of human motivations (Gordon G, 2000). The individual beliefs and values are usually deeply embedded and fundamental and therefore, difficult to discard them in order to support the provisions of political order. Since globalization has undermined the nation state which could have guarded the treasured norms of the society, therefore religion is considered as the essential possibility that can fill the vacuum created by globalization. Besides, a fundamental idea may not necessarily be linked with any particular religion only. It could be moral, political or cultural beliefs that are highly regarded by individuals and could not be shun away even for other governing principles.

The two ways adopted by the religious fundamentalist to react to the professed corruption of the current society are "passive fundamentalism" and "active fundamentalism". The first one attempts to draw from the mainstream and build communities of supporters. The later one takes the path of resistance and struggle. This makes fundamentalism infested by terrorism. According to Bamikole "the motivation for terrorism has been manifested in the combination of religion, nationalism and fanaticism" (1991). The arrangement of these rudiments is the main reason that terrorist groups usually cluster in regions where individual and groups believe that the revival of the world can only be possible through holy wars. 
The difference between old terrorism and new terrorism is defined by David Carlton as "territorial grievances involving demands for independence from colonialism as old terrorism" (2003). The common features of old terrorists are identified as having specific, well defined and articulated goals. Targets are identifiable individuals and properties with no intention to maximize bloodshed (Ibid). Whereas, "new terrorism" is comprised of having "broader networks across territorial borders, they are nihilistic; they are inspired by fanatical religious beliefs; they are willing to seek martyrdom through suicide; they rarely set aims that appear remotely attainable; they give no warnings; they do not engage in bargaining; they are willing and even eager to carry out the mass slaughter of non-combatants" (Ibid). Yet, David Carlton failed to identify state terrorism which is responded by the "new terrorism" (Bamikole).

However, the confines that are identified to distinguish Old Terrorism from New Terrorism are not mutually restricted. There could be organizations regarded as primitive but they can also be tagged as New Terrorism despite not being nihilistic or inspired by fanatical religious beliefs, for example, Hamas, which has been active in pursuing an independent Palestine and using terrorist tactics. Furthermore, it is quite doubtful that a terrorist organization carries out its attacks without a rational goal to accomplish. Additionally, the 2004 attacks on passenger trains in Spain, which altered the electoral results, suggest globalization in form of internationalism is being confronted across local and national borders (Ibid).

\section{INSTITUTIONS OF GLOBALIZATION AND TERRORISM}

Research on causes of terrorism is inconclusive. There are multitudes of sources of terrorism identified such as ethnicity, nationalism/separatism, poverty and economic disadvantage, globalization, (non) democracy, Western society, disaffected intelligentsia, dehumanization, and religion. However, no single reason being convincingly attributed to it (Keet, Maria, 2003). Yet it is worth noting that terrorist resort to institutions of globalization and uses its resources effectively. It is important to look into the institutions in the context of globalization and terrorism to arrive at a balanced understanding of them.

Institutions are considered to be the basis of social life. They guide and regulate conflict and thus ensure stability in society (Campbell, 2004). They are defined to be formal and informal rules, monitoring and enforcement mechanisms, and systems of meaning within which individuals and organizations operate and interact with each other. According to Douglas North "Institutions as sets of formal and informal rules and the monitoring and sanctioning mechanisms those cause actors to comply with these rules" (1990), and hence reduce transaction cost. Thelen and Steinmo defined institutions to be the formal and informal rules and procedures that structure conduct (1992). Besides, institutions are referred to as informal, common, and taken-for-granted cultural frameworks, scripts, and cognitive schema (Jepperson 1991). Hence the formal and informal rules, monitoring and enforcement mechanisms, and systems of meaning within which individuals operate and interact with each other and reflect the power of those who made them (Campbell, 2004). The institutional theory of economics further stipulates that individuals operate within the given rules, yet they also strive to change those rules when it pays them to do so. It further suggests that society follows the "adaptively efficient path of development" and that the institutional changes lead to reduced transaction costs and expanded scope for individual initiative. The "adaptively inefficient path of development" is the situation when institutional changes lead to higher transaction costs and reduced opportunities for wealth creation. (North, 1990)

In the context of globalization, institutions may perhaps be considered as "massive internationalist intervention" (Ferguson, 1994). Having the potential to successfully generate and execute ventures, while influencing governmental systems. This invincible force is identified as "development industry" also called the "development apparatus", made up of the many international agencies funded by the rich countries of the world in the name of promoting development (Ibid). According to one of the economic views "globalization from above" refers to endorsement of globalization led by the Transnational Corporations (TNC) and its principal agents supported by transnational institutions like WTO and treaties like NAFTA (Sklair, 1995). This view considers globalization as inevitable (Brecher, Jeremy, et al. 2000). On the other hand "globalization from below" refers to resistance to globalization by ethnic, cultural, religious movements as reaction to the potent agenda of transnational capitalism (Barber, Benjamin,1992) along with the role of civil society and non-governmental organizations (NGO) in ensuing social change in their respective environment (Fox, Jonathan, et al. 1998).

Jackson observed that there is a "middle space" where the advocates and promoters of "globalization" from above come together with the "discontents" from below" (Jackson, 2003). According to him the development institutions and its workers are the significant constituent, that is, "the middle space" of the globalization process. They operate within the framework of multiple agendas by incorporating both the views. The principal task of 
development institutions also referred as "globalizers" by Jackson is to do the spadework for the expansion of capitalism along with other non-economic agendas.

Jackson further argues that globalization is a process of multiplicity of agendas (Jackson, 1998) where some are principal and others are marginal "global cultural scripts" which are equivalent of institutions that restrain the behavior of nations in global context (Boli, John, et al. 1997). These constraints are created by transnational institutions such as the United Nations and the World Bank. The apparatus of multiplicity of agendas is apprehended by the richest nations of the world. These nations include Group of Seven that direct $75 \%$ of all aid to the developing world (OECD. 2001). Besides these are the main financiers of multilateral aid agencies like the World Bank and United Nations. Additionally the Organization of Economic Cooperation and Development (OECD) is a group of 22 countries which gives economic assistance to the developing world. These countries dictate the resource allocation and decision making process at the World Bank, International Monetary Fund and the World Trade Organization (Ibid). Jackson (1998) infers that "development assistance and the international development profession are the primary mechanisms through which the imposition of these multiple agendas occurs." Resultantly these richest countries serve their mutual interest by imposing explicit agendas upon recipient countries by giving tens of billions of dollars in the name of donors' assistance every year to the developing countries (OECD. 2002) which in fact benefits the donors in the long run (Jackson, 2003).

Nevertheless, it is quite disappointing to note that there are hardly any watchdog systems in place that can monitor the actions of these institutions for accountability and responsibility (Jackson, 1998). Therefore, globalization is not only about the issue of state sovereignty but also about the "accountability" (Fox, Jonathan, et al. 1998). The new social arrangement created between the donors and recipients is the globalization of political processes is called "Transnational State" (Robinson, 2005). Thus global agendas are successfully carried out due to intrinsic professional proficiency in the international development organizations (Jackson, 1998). Whereas local agendas are successful only with the support of international organizations, however, it receives only marginal benefits. Moreover, hidden costs and risks associated with development assistance are usually overlooked due to deficient accountability mechanisms which ensure the maximum gain to the donor countries.

Given the multiple causes of terrorism and exploits of the transnational agenda, the aggrieved from all over tend to converge to resist the corrupting effects of globalization. However, the failure to differentiate between terrorist and criminals is opening new horizons where both of them congregate to achieve their respective interests in most effective and efficient manner.

\section{CHALLENGES OF GOVERNANCE IN THE ERA OF GLOBALIZATION}

Terrorism fed upon Globalization and vice versa. The irony of the fact is that global crime and terrorists are using these capabilities more effectively and efficiently, hence reducing their transaction costs. The major reason behind their proficiency lies in getting free ride over the infrastructure developed by the global capital. The loopholes in bureaucratic governance of trade have led to greater exploits by the transnational crime in terms of reduction in operational risk. The rise in drugs, arms and human trafficking suggests that illicit activities are also blended with legitimate dexterity (Shelley, Louise. 01 February 2006). Shelley presented the concept of "unholy trinity" of crime, corruption and terror wherein these institutions are created and facilitated to globalize the crime networks sometimes blended by movement from crime to terrorism (Ibid). Consideration of crime as a marginal issue to terrorism has led to a swift rise in terrorist networks hence making terrorism as an evolving risk.

The myth of globalization lies in the fact that humanity is seen only in political as being dominant force followed by economic, cultural, or religious terms. According to Eric Voegelin "political order is directly related to religious experience" (Sigler John, 2000). This view has been furthered by Mary Jo Leddy, observing that "19th century was an era of sexual repression, and the 20th century is a time of spiritual repression" (Ibid). As a consequence of the profound social, political, and cultural transformations that have occurred since the rapid growth of globalization, it has become critical for the professionals to embrace requisite skills and technologies to address the issues related to trans-cultural activities. According to O'Rourke and Williamson (2000) the present era of globalization is "characterized as the rising dominance of skills and new technologies" The first Human Development Report in 1990 stated in its opening lines "The real wealth of a nation is its people. And the purpose of development is to create an enabling environment for people to enjoy long, healthy and creative lives. This simple but powerful truth is too often forgotten in the pursuit of material and financial wealth". This phrase reflects the importance of people in the global world.

According to the doctrine of globalization, concepts of workplace flexibility and the virtual office has been incorporated in the human resource systems. Moreover, new skills and capabilities like language capabilities, 
internet and computer literacy, cultural knowledge, transnational issues and maintenance of international workforce has been developed in the functional areas of Human Resources, the five "R's", Resourcing, Recruiting, Retaining the talent, Retraining and Restructuring. Besides, performance management and training and development are critical needs of the time (Articlebase. June 26, 2009). Given the bounties of globalization, the criminals have also integrated their activities accordingly for the same rationale. Illegitimate businesses are also drawing benefits of global labor and markets by launching international amenities to cater to their needs for production, marketing and distribution. Due to rapid innovations in communications and transportation systems, the criminal groups and organizations have expanded their geographical jurisdictions as well. The tenets of globalization are also critical to promote crime.

Realizing the progress of globalization and magnitude and potential of terrorists, what should be done? Should the globalization process be stopped, retarded or terror threats be ignored? Given the topic of this paper, answers need to be derived from various theories of institutions. Dani Rodrik (2000) argues that global markets without global governance - are unsustainable. The alternative is a renewed "Bretton-Woods compromise:" preserving some limits on integration, along with some more global rules to handle the integration that can be achieved. Those who would make a different choice — toward tighter economic integration - must face up to the corollary: either tighter world government or less democracy.

Rodric conveyed two thoughts; first there are inherent limitations to how far we can push global economic integration. It is neither feasible nor desirable to maximize what Keynes called "economic entanglements between nations (Keynes, 1933). Second, within the array of feasible globalizations, there are many different models to choose from. Each of these models has different implications for whom we empower and whom we don't, and who gains and who loses. However, two facts ought to be recognized, that is, the role of state and the market and secondly that there in no exclusive mechanism to plan and specify these roles universally. Institutional diversity is a significant impediment to full economic integration and perform a valuable economic (as well as social) role. The removals of formal restrictions on trade and investment have mostly disappeared, however, regulatory and jurisdictional discontinuities created by heterogeneous national institutions constitute the most important barriers "transactional cost" to international commerce.

The survey of developed states of the world suggest that those who followed the indigenous approach in devising their institutional infrastructure fared well and others who followed the "one best" way had not succeeded in either achieving their development targets or social recognition. Hence generating chaos and governance issues leading to spread of criminal and rise of terrorism. Therefore the insertion of domestic agenda based upon local needs for development and governance is critical.

What is generally less well understood is that the institutional basis of market economies is not unique. Creating, regulating, stabilizing, or legitimating markets are functions that do not map into specific institutional forms. The survey of developed states of the world suggests that those who followed the indigenous approach in devising their institutional infrastructure fared well and others who followed the "one best" way had not succeeded in either achieving their development targets or social recognition. Hence generating chaos and governance issues leading to spread of criminal and rise of terrorism. Therefore the insertion of domestic agenda based upon local needs for development and governance is critical.

Perhaps the best way to observe that market economies are compatible with diverse institutions is to note the variety that exists among today's advanced countries. The United States, Europe, and Japan are all successful societies: they have each produced comparable amounts of wealth over the long term. Yet their institutions in labor markets, corporate governance, regulation, social protection, and banking and finance have differed greatly. There are good reasons for institutional diversity, and for why national institutions are resistant to convergence. For one thing, societies differ in the values and norms that shape their institutional choices. There is a second, subtler reason for the absence of convergence in institutional arrangements. Different elements of a society's institutional configuration tend to be mutually reinforcing (Rodrik, 2002). With such mutual dependence among the different parts of the institutional landscape, anything short of comprehensive change can be quite disruptive, and is therefore difficult to contemplate in normal times. The result is what economists call "path dependence" or "hysteresis:" once the institutional setup performs reasonably successful (and often when it is not), it gets locked in. The last major category of reasons for institutional diversity has to do with the special needs of developing nations. Sparking and maintaining economic growth often requires institutional innovations that can depart significantly from American or Western ideals of "best practice."

The Chinese experience represents not the exception, but the rule: transitions to high growth are typically sparked by a relatively narrow range of reforms that mix orthodoxy with domestic institutional innovations, and 
not by comprehensive transformations. All these pieces of evidence point to the same conclusion: national borders continue to act as serious impediments to economic exchange, even though formal trade barriers have all but disappeared. The key point is that national borders, and the institutional boundaries that they define, impose a wide array of transaction costs. Institutional and jurisdictional discontinuities serve to segment markets in much the same way that transport costs or import taxes do. Transaction costs also result from national differences in regulatory regimes and in the rules of doing business-informal as well as legal. That such differences raise the cost of buying, selling, and investing across national boundaries is one of the most frequent complaints heard from businessmen around the world. Indeed, trade conflicts are increasingly the consequence of these differences. Besides, in democracies, when the demands of foreign creditors collide with the needs of domestic constituencies, the former eventually yield to the latter (Ibid).

\section{GLOBALIZATION AND PAKISTAN}

The institutional debate in the preceding section concludes that Pakistan has become anarchic due to institutional incompetence. It is evident that transactional cost to carry out the process of globalization in Pakistan has exceeded its benefit for the country and the people. Regardless of the question that who is responsible for the entire debacle, it is imperative to take the inventory of the situation into consideration and the effective measures within the institutional diversity be devised to carryout globalization through indigenous solutions to combat terrorism and fight back poverty through local economic agenda.

The development history of Pakistan establishes the insights into the concept of globalization when realized in a conceited manner. Pakistan embarked its development agenda as an ally in the cold war by receiving $\$ 2$ billion from 1953 to 1961 (Root, 2005). During the period economic growth as per Gross National Product (GNP) grew to a record high of $10 \%$ in following ten years. However this brief period intensified social inequalities and "rent seeking" was legitimized. This period witnessed the capacity building process to embrace global percepts. A large number of technocrats were trained by the US to create the pool of future policy makers and hence the global interest. The end of Ayub Khan's military rule saw transition to civilian rule in 1971. The United States assistance was suspended during this period due to the Indo-Pakistan wars and following Pakistan's construction of a uranium enrichment facility in 1979. This period observed a decline in growth rate of GNP from $6 \%$ to $4.5 \%$. (Center for American Progress, August 21, 2008). Besides, half the country was lost in the process.

However, Pakistan remerged as an ally in the 1980s during the Soviet Union's occupation of Afghanistan and Zia's military rule saw the opening of US bilateral aid to Pakistan for its proxy war against Soviet forces in Afghanistan in the name of Islamic jehad for which he received $\$ 3.2$ billion from US as aid package (Root, 2005). This phase represents the war fought by the Afghan fighters (mujahideen), funded by the Pakistani ISI (Inter Services intelligence) and the US CIA, against the Russian invasion of Afghanistan. During this period Pakistan was rigorously provided arms and tactical training to Afghani fighters. US-AID to Pakistan averaged $\$ 0.8$ billion per annum, one of the highest in the history of US-Pak relations (Ibid). Yet Zia lost a unique opportunity to translate a combination of opportunities like significant western aid and inflows of remittances from overseas Pakistanis into investment in productive sectors, infrastructure and human development, including education.

Nonetheless, following the withdrawal of Soviet troops in the late 1980s, assistance to Pakistan took another nosedive. This period saw the democratically elected government of Benazir Bhutto observed a fall in economic growth rate $6.8 \%$ from 1986-1988 to 8\% in 1989 (Mullick, 2004). The second economic boom in the absence of US-assistance was observed in 1996, right before the nuclear tests May 28, 1998, when Pakistan's economic growth rate grew from $2.1 \%$ in 1993 to $6.7 \%$ in 1996 (Ibid). However, this boom was very short lived. In 1998, Pakistan tested its nuclear power by detonating underground nuclear bombs, which resulted in sanctions from the US, European Union, IMF and World Bank. The economic growth rate hit its lowest point, 1.8\% in 1998 (Ibid).

Due to selfish transnational interest, the basic tenets of globalization were compromised by support to military regime and encouragement of Islamization in Pakistan. Proliferation of drugs supplied finances for weaponization and promoted crime. While the growth of madrassahs developed mechanism of capacity building for jihadis and influx of millions of Afghan refugees created economic, social and security problems. Moreover, institutions of money laundering created by drugs and weapons ran the good money out of circulation. Hence the last of the Cold War conflicts led to the first military intervention of the 21st century in reaction to 9/11 (Lodhi, 2010).

General Pervez Musharraf's military coup in October 1999 and assumption of power replaced yet another elected prime minister, Nawaz Sharif. He pursued the global agenda by inducting technocrats and professionals of transnational regime to introduce economic and governance reforms. However, these changes were not rapid 
enough to bring economic growth which further declined to 2.1 in 2001 from a $4.1 \%$ in 2000 , mainly attributed to terrorist attacks of September 11, 2001 (Ibid). After Pakistan's public announcement of allying with the US in the war against terrorism, US assistance was disbursed at an average of $\$ 0.8$ billion per annum from 2001 to 2003 and unsurprisingly, almost all of the aid provided since has gone to military operations (Center for American Progress, August 21, 2008). This increased economic growth to $4.8 \%$ by 2003 . However, the US and transnational vested interest once again compromised the precept of globalization by supporting, appreciating and glorifying military ruler.

President Musharraf joined US as an ally in the Global War on Terror and agreed unequivocal support which included realigning domestic political institutions to serve U.S. interests; granting the U.S. access to Pakistan's airfields; and overtly pledging support to the U.S. coalition (Zalman, Amy). However, unlike Zia, he not only had misappropriated the aid (Gannon, 2009) but also compromised Pakistan's sovereignty by tacitly allowing the drone attacks carried out by the US hence killing thousands of civilians since 2004. According to Pakistani authorities, from January 14, 2006 to April 8, 2009, 60 U.S. strikes against Pakistan killed 701 people, of which 14 were Al-Qaeda militants and 687 innocent civilians (Wikipedia). Besides, he took "extra-judicial and extra-constitutional' step of invoking emergency in the country in order to depose the chief justice of the Supreme Court of Pakistan and other non-complying judges of superior and lower judiciary. Hence he tempered with the existing institutions (Hussain, 2007). Moreover, the number of unregistered madrassahs grew 10,000-13,000 in 2001, to over 40,000 in 2008 (Dewi, 2009).

It is interesting to note that the entire US and transnational assistance given to Pakistan since its independence had failed to develop institutions of trust among both. Moreover, foreign assistance has historically been skewed favorably towards the undemocratic governments and anti-global elements. Additionally, the US and the West completely failed to realize the domestic compulsions of Pakistan and its social structure. Additionally, US always failed to finish its agenda in the region and lately have demonstrated an absolute disregard to the security of the people of Pakistan. Furthermore, the development assistance failed to acknowledge the unrealistic demands attached to the aid provided in terms of structural adjustment programs and others that left the country in economic and political mess.

Notwithstanding the current state of chaos, the institutional analysis of globalization suggests that Pakistan should take a "local approach" to fixing its economic and governance institutions. This includes a compromise on part of the US and transnational assistance to respect the people, social constructs the religion and economic compulsions of Pakistan by restraining intervention. Secondly, mutually agreeable and measurable targets should be set to purge terrorism and terrorist from Pakistan. Moreover, Pakistan needs to ensure the vigilance in utilization of assistance and realization of the mutually agreed goals. It needs a careful construction of institutional infrastructure with inherent mechanism of inputs leading to desirable outputs and means to audit and appraisal. To initiate such an ambitious institutional restructuring, US and transnational agencies should write-off the external debt of Pakistan approximately US $\$ 60$ billion (IndexMundi). This will give a breathing space to the country to device its indigenous agenda to fight terrorism as well as to arrive at economic prosperity. Beside, given the importance of Pakistan as a crucial ally in war against terrorism, and the failure of US and its allies to curb terrorism, $\$ 60$ billion is a small percentile of the financial resources being spent elsewhere for the same reason.

\section{CONCLUSION}

The hegemony of US and the transnational assistance has failed to achieve the targets of globalization in Pakistan. The failure to devise mutual set of indicators to measure progress and transparency in repetitive partnerships led to emergence of trust deficient institutions on part of both. The current state of fragile security, political and economic situation in Pakistan and historically deteriorating institutional mechanisms, it is imperative to strengthen Pakistani society and institutions against militant subversion. Otherwise, given the fact that none of the states in the region including the neighboring Afghanistan have a genuine democratic government and that all these countries are Muslim states and do not have sufficient incentives to give up their respective identities, so any spillover on part of the anti-global interest will dissent the US and transnational interest thereby, affecting global security. Therefore it is essential on part of the US as leading force against war on terrorism to take a realistic stock of the current situation along with its strategic partners like Pakistan and focus on developing mechanisms to shape the future discourse. It is essential to note that no policy on part of US will pay back positively until the will of the people is accommodated. 


\section{References}

Appadurai, A. (Ed.). (2001). Globalization. Durham: Duke University Press.

Articlebase. (June 26, 2009). Challenges faced by human resource managers in the era of gloablization. [Online] Available:

$\mathrm{http} / / / \mathrm{www}$.articlesbase.com/human-resources-articles/challenges-faced-by-human-resource-managers-in-the-era -of-gloablization-995167.html (August 21, 2010)

Bamikole, Lawrence. O. Globalization and terrorism discourse. [Online] Available: http://ojs.mona.uwi.edu/index.php/cjp/article/viewFile/283/183 (August 21, 2010)

Bamikole, L.O. (1991). Of nationalism and fanaticism: The gulf war in retrospect. Journal of Issues in Social Science. Vol. 1, No. 2. pp. 22-29.

Barber, Benjamin. (1992). Jihad Vs. McWorld. Atlantic Monthly. March 53- 63. also see Giddens, Anthony. (2000). Runaway World: How Globalization is reshaping our lives. New York: Routledge and Robinson, William I. (1996). "Globalisation: nine theses on our epoch. Race \& Class v. 38 (Oct./Dec. '96) pp. 13-31

Boli, John., and Thomas, George. M. (eds.). (1997). World polity formation since 1875: World culture and international non-governmental organizations. Stanford: Stanford University Press.

Brecher, Jeremy., Tim, Costello., and Brendan, Smith. (2000). Globalization from below. The Nation, December 4, 2000, pp. 19-22.

Campbell, John, L. (2004). Institutional change and globalization. Princeton University Press.

Center for American Progress. (August 21, 2008), U.S. aid to Pakistan by the numbers. [Online] Available: http://www.americanprogress.org/issues/2008/08/pakistan_aid_numbers.html (August 21, 2010)

Chanda. Nayan. (November 19, 2002). What is globalization? YaleGlobal. [Online] Available: http://yaleglobal.yale.edu/about/essay.jsp (August 21, 2010)

Dewi, Kezia. (March 30, 2009). Pakistan and Terrorism. Associatedcontent. $\mathrm{http} / / / \mathrm{www}$. associatedcontent.com/article/1588961/pakistan_and_terrorism.html (August 21, 2010)

Ferguson, James. (1994). The Anti-politics machine. Minneapolis: University of Minnesota Press.

Fox, Jonathan A., and Brown, L. David. (Eds.). (1998). The Struggle for Accountability: The World Bank, NGOs and grassroots movements. Cambridge: The MIT Press.

Gannon, Kathy. (May 10, 2009). Billions in US aid to Pakistan never reached army, generals say. The Huffington Post. [Online] Available: http://www.huffingtonpost.com/2009/10/05/billions-in-us-aid-to-pak_n_309283.html (August 21, 2010)

Gordon, G. (2000). Politics, religion and national identity. Philosophy and Public Affairs Supplementary to Philosophy. pp. 73-84.

Hendrik Hertzberg. (2001). The New Yorker (September 24).

Hussain Gul Jammas. (07 November, 2007). Musharraf's coup against judiciary. Countercurrents.org. [Online] Available: http://www.countercurrents.org/hussain071107.htm (August 21, 2010)

IndexMundi. Pakistan debt $\quad-\quad$ External. [Online] Available: http://www.indexmundi.com/pakistan/debt_external.html

Introduction to anti-globalization - Definition and resources. [Online] Available: http://www.anti-marketing.com/anti-globalization.html (August 21, 2010)

Jackson, J. T. (2003-08-16). Theorizing the agents of globalization: The International development profession and the emergent global state". Paper presented at the annual meeting of the American Sociological Association, Atlanta Hilton Hotel, Atlanta, GA Online <.PDF>. 2009-05-26. [Online] Available: http://www.allacademic.com/meta/p106966_index.html (August 21, 2010)

Jackson, Jeffrey. T. (1998). Doing development: Global planners and local policy in Honduras. Ph.D. Dissertation. University of Texas-Austin 1988.

Jepperson, R. L. (1991). Institutions, institutional effects, and institutionalism. In Walter Powell and Paul DiMaggio (Eds.). The new institutionalism in organizational analysis. University of Chicago Press.

Keet C. Maria. (2003). Terrorism and game theory: Coalitions, negotiations and audience costs. [Online] Available: http://www.meteck.org/TerrorismGameTheory.pdf (August 21, 2010) 
Keith Porter. (December 31, 2004). Globalization and terrorism. MercyCorps. [Online] Available: http://www.globalenvision.org/library/8/703 (August 21, 2010)

Keynes, John Maynard. (1933). National self-sufficiency. Yale Review, Vol. 22, No. 4, pp. 755-769.

Lodhi, Maleeha. (September 20, 2010). The burden of history. Khaleej Times. [Online] Available: http://www.khaleejtimes.com/DisplayArticle08.asp?xfile=data/opinion/2010/September/opinion_September84.x ml\&section=opinion (August 21, 2010)

MercyCorps. (November 25, 2003). What is globalization? [Online] Available: http://www.globalenvision.org/library/8/567/ (August 21, 2010)

Mullick, Haider. (2004). US foreign aid and economic growth: A post-9/11 case study of Pakistan as a key ally in the war against terrorism. Published in the Proceedings to the Pennsylvania Economic Association Conference Summer 2004. [Online] Available: http://haidermullick.com/Documents/US\%20Foreign\%20Aid\%20and\%20Pakistan.pdf (August 21, 2010)

Naim, M. (2003). The five wars of globalization. (NBER Working Paper No. 7632). Foreign Policy (January/February): pp 29-37.

North, Douglas C. (1990). Institutions, institutional change and economic performance. Cambridge University Press.

Rawls, J. (1993). Political liberalism. New York: Columbia Press.

Robinson, William. I. (2005). Gramsci and globalisation: From nation-state to transnational hegemony. Critical Review of International Social and Political Philosophy. Vol. 8, No. 4, 1-16, December 2005.

Rodrik, Dani. (July 2002). Feasible globalizations. (NBER. Working Paper 9129). Cambridge, MA: National Bureau of Economic Research.

Root, Hilton. (2005). The political economy of state failure. The Milken Institute Review. [Online] Available: http://mason.gmu.edu/ hroot2/Pakistan\%20The\%20Political\%20Economy\%20of\%20State\%20Failure.pdf (August 21, 2010)

Rosecrance, Richard. (2003). Security and globalization in the context of international terrorism. [Online] Available: http://www.international.ucla.edu/article.asp?parentid=3877 (August 21, 2010)

Rourke. Kevin., and Jeffrey, G. Williamson. (April 2000). When did globalization begin? (NBER. Working Paper 7632). Cambridge, MA: National Bureau of Economic Research. [Online] Available: http://www.nber.org/papers/w7632.pdf (August 21, 2010)

Shelley, Louise. (01 February 2006). The globalization of crime and terrorism. America.gov. [Online] Available: http://www.america.gov/st/econ-english/2008/June/20080608103639xjyrreP4.218692e-02.html (August 21, 2010)

Sigler John. (2000). A theory of globalization. In Farhang Rajaee (ed.). Globalization on trial: The human condition and the informationc civilization. International Development Research Centre. [Online] Available: http://www.idrc.ca/openebooks/909-7/ (August 21, 2010)

Sklair, Leslie. (1995). Sociology of the global system (2nd ed.). Baltimore: The Johns Hopkins University Press.

Thelen, K., and S. Steinmo. (1992). Historical institutionalism in comparative politics. Historical institutionalism in comparative olitics: State, society, and economy. In S. Steinmo., K, Thelen., and F, Longstreth. New York, Cambridge University Press.

Wikipedia. Drone attacks in Pakistan. [Online] Available: http://en.wikipedia.org/wiki/Drone_attacks_in_Pakistan (August 21, 2010)

Wikipedia. History of the United States. [Online] Available: http://en.wikipedia.org/wiki/History_of_the_United_States (August 21, 2010)

Zalman, Amy. Terrorism timeline: Pakistan and the global war on terror: Pakistan plays friend and foe to U.S. About.com. [Online] Available: http://terrorism.about.com/od/globalwaronterror/tp/Pakistan---Terror-War-Timeline.htm (August 21, 2010) 